PERSUASIVE STRATEGIES OF SAMOSIR PROMOTION IN "Visit Samosir" FACEBOOK PAGE

\author{
AN ARTICLE \\ Submitted to Fulfill the Partial Requirements \\ For the Degree of Sarjana Sastra
}

By:

RENNI SAGALA

Reg. Number: 2131220014

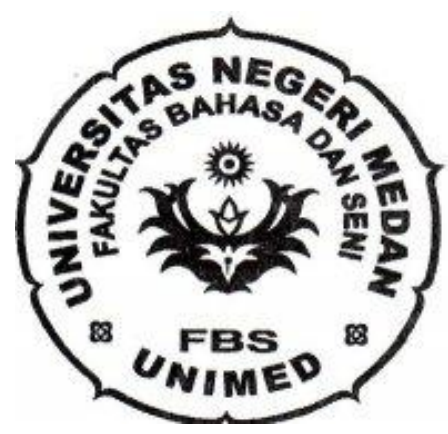

ENGLISH AND LITERATURE DEPARTMENT

FACULTY OF LANGUAGE AND ARTS

STATE UNIVERSITY OF MEDAN

2017 
ARTIKEL

\title{
PERSUASIVE STRATEGIES OF SAMOSIR \\ PROMOTION IN “Visit Samosir" FACEBOOK PAGE
}

\author{
Disusun dan Diajukan oleh:
}

Renni Sagala

NIM. 2131220014

Telah diverifikasi dan dinyatakan memenuhi syarat

Untuk diunggah pada jurnal online

Medan, Juli 2017

Menyetujui

Dosen Pembimbing Skripsi I

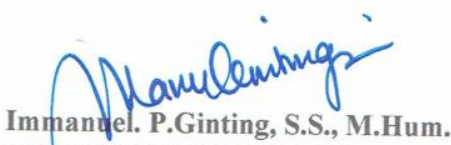

NIP. 198306102008011007

(

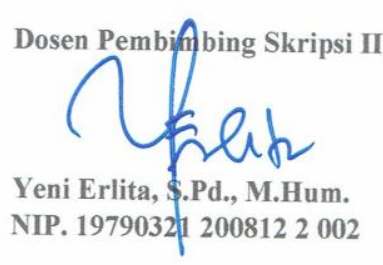

Ka. Prodi Sastra Inggris

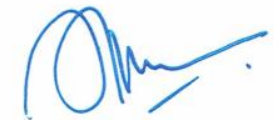

Juli Rachmadani.Hsb, S.S., M.Hum

NIP. 198207112008012008 


\title{
PERSUASIVE STRATEGIES OF SAMOSIR PROMOTION IN "Visit Samosir" FACEBOOK PAGE
}

\author{
*Renni Sagala \\ **Immanuel Prasetya Ginting, S.S., M.Hum \\ **Yeni Erlita, S.Pd., M.Hum
}

\begin{abstract}
Sagala,Renni. Reg. No. 2131220014. Persuasive Strategies of Samosir Promotion in Visit Samosir Facebook Page. A Thesis, English Literature, Faculty of Language and Arts, State University of Medan. 2017

This study deals with the Persuasive strategies of Samosir promotion in visit samosir facebook page. The objective of the study are to find out the types of persuasive technique of samosir promotion in visit samosir facebook page, and to describe the strategies of persuasive of samosir promotion in visit samosir facebook page. This study was conducted by using Descriptive qualitative method. The data was collected from http://visitsamosir.com. There were 60 status from May of 2016 to May of 2017.The findings found that there are only six from seven types of persuasive technique are used in visit samosir status and they are rationalization (17 status), identification (3 status), suggestion (32 status), compensation (6 status), projection (2 status), and displacement (1 status). And the strategy of persuasive that used in visit samosir facebook page were Logos, Phatos, Ethos. Mostly, the user use the logical reason (Logos). It caused the user need to show the fact or logic reason to get belief from the visitor. So, the visitor become interest to visit the tourism.
\end{abstract}

Keywords: Persuasive, Samosir Tourism, Facebook, Visit samosir

\footnotetext{
*Graduate Status

**Lecturer Status
} 


\section{INTRODUCTION}

\section{Background of The Study}

Language is the method of human communication, either spoken or written, consisting of the use of words in a structured and conventional way. The use of language is the object study of discourse analysis. This study concerns on linguistics, such as how languages used in persuading people during communication. There is an art of course that is Rhetoric. Keraf (2000:118) argued "Rhetoric means the use of language as an artistic technique, both oral and written are based on a well-structured knowledge". Deals with it, there are two improtant aspects which people should to understand about rhetoric. The first is knowledge about language and it's used. The second knows the object that will be the target of language's user.

In this era globalization, the ability to persuade other people is needed. It can be seen from some phenomenons: many big tourism instances try to persuade the people to visit the tourism that they manage. The ability to persuade or convince the people are not easy; it used a skill or strategy to make the other people believe what the speakers mean and want which is called by Persuasive Strategies. Persuasive strategy is a skill or strategies to influence the other people or a group to take a certain action. Persuasive strategies have some areas to be investigated such as Politic, Advertising, Social, and also in Tourism Promotion.

Keraf (2000) identified the types of persuasive technique such as Rationalization, Identification, Suggestion, Conformity, Compensation, Projection, and Displacement. While, Aristotle (1854) described there are three of persuasive strategies (Phatos, Logos, Ethos) that used to influence the other. Based on the theories, the researcher found out the types of persuasive technique that used in visit samosir Facebook page and describing the strategies of persuasive that use in it.

Social media is an interaction among people in which they create, share, and/or exchange information and ideas in virtual communities and network. In this modern area, Social media as the collective of online communications 
nnels become one of applying of language use. It can see from the news, advertising, promoting, online shopping, etc. The users of each this transaction persuade the viewers to be influence or to be believe something that they have shown. They use the statement and Picture to complete their method to persuade people. Social media have the most favorite site, such as Facebook, instagram, twitter, etc. In this case, the researcher focuses in Samosir Tourism Promotion in Facebook page.

\section{REVIEW OF LITERATURE}

The term persuasive or persuasion has been defined by many experts in slightly different ways. According to Gorys Keraf (2000:118) defines that persuasion is an art of verbal with the intention to assure someone to do something appropriate with the speaker's purpose for this moment or the present time. The ability to persuade someone using words or another thing can be included as an art. It needs a specific skill to organize words and another aspect in order to influence people for doing something using verbal or non-verbal way is called persuasion.

Persuasive is an effort to convey information by means analyzing and understands the public or audience accurately. Then, the purpose is to influence or persuade the attitude, view or behavior of audience, in order that what speaker's aimed run well by audience's awareness without violence or an encouragement from other, at the moment or at the present time. By using persuasive, people will be able to ask another people doing something appropriate with their pretension. People do not need to force another people doing something they want. They only need to construct the words in a good way that people will believe and be interested in, therefore, mastering persuasion technique and strategies is very important thing in communication.

1. Persuasive Technique

Persuasive technique is discussing about the technique or the strategies used to influence people to believe and to be interested with the speaker.

There are seven types of persuasive technique that indenfied in visit samosir facebook page, there are:

a. Rationalization is the use of mind process to give a justification for a certain problem 
b. Identification is an identify the receiver; the users have to analyze their viewers and the situation accurately, whether they are adult, teenager or children.

c. Suggestion is an effort to persuade or influence people to accept the certain conviction without giving a principle or logical belief to the persuaded people.

d. Conformity is a desire or an action to make something similar with something else.

e. Compensation is an action or a result from an effort to look for a substitute for something unacceptable or indefensible circumstance.

f. Projection is a technique to make something that had become the subject object.

g. Displacement is a process compare the tourism with the other that their own is the best than the other.

2. Strategies of Persuasive

Persuasive strategies is a plans or steps of an action to make someone believe something by giving them a good reason to do a certain purpose.

Aristotle (1854) defined that there are three strategies to persuade the viewer's attention. They are Ethos, Pathos and Logos.

a. Ethos: an appeal to credibility or character.

b. Pathos: an appeal to emotion.

c. Logos: an appeal to logic or reason.

\section{METHODOLOGY}

This research focused on descriptive qualitative method because the intention of this research is to identified the types of Persuasive technique and described the strategies of persuasive are applied in Visit Samosir facebook page. Descriptive qualitative research seeks to provide the goals using the data in form of words, this research is not using number (quantitative). Descriptive qualitative method is nonquantitative method to describe what is. It means the qualitative research is empirical research where the data are not in the form of numbers. 
The source of data for this research is Facebook status was taken from http://visitsamosir.com/. The data of this research is each sentences of Visit samosir's Status. There were 60 status selected from visit samosir facebook page. The data collected by documentary technique. Copying and printing out the status from the visit samosir facebook page. They identified based on the kinds of persuasive technique and analyzed based on the strategies of persuasive.

\section{FINDINGS AND DISCUSSION}

\section{Findings}

From 60 status of visit samosir facebook page as the data that the researcher has been identified, the researcher found only 6 types of persuasive technique that user used in visit samosir status.

\begin{tabular}{|l|l|l|}
\hline No & Persuasive Technique & Account of the Data \\
\hline $\mathbf{1}$ & Rationalization & 17 Statuses \\
\hline $\mathbf{2}$ & Identification & 3 Statuses \\
\hline $\mathbf{3}$ & Suggestion & 31 Statuses \\
\hline $\mathbf{4}$ & Conformity & - \\
\hline $\mathbf{5}$ & Compensation & 6 Statuses \\
\hline $\mathbf{6}$ & Projection & 2 Statuses \\
\hline $\mathbf{7}$ & Displacement & 1 Statuses \\
\hline & Total & $\mathbf{6 0}$ Statuses \\
\hline
\end{tabular}

The usual strategy that the user used along the research period is Logos strategy.

The viewers of visit samosir facebook page need the logical reason to make them believe for promotion that the user show.

\section{Discussion}

From the seven types of persuasive techniques based on Keraf's theory (2000), there were rationalization, identification, suggestion, conformity, compensation, projection, and displacement, and the most commonly used by the user of visit samosir is the suggestion type. The user tried to invite the viewers by suggesting them to choose 
samosir as a tourist destination. They present some activities to be carried out by the tourism office of the samosir in question so that the viewer doesn't think along and as soon as they will visit the Samosir Island. Except the activities organizing, the user also describes the uniqueness of Samosir to get the attention of the viewers.

Based on the Aristotle's theory (1954) there were Logos, Phatos, Ethos, Logos strategy is the most commonly used strategy in promoting samosir tourism on visit samosir facebook page. The user invites the viewers by presenting the logical statements or reasons by giving some facts such as describing some of the features of the tourism. For example, the user makes a statement " Green and fertile fields, Samosir island is a beautiful land of Agriculture ", then the user adds a photo about Samosir based on the statement he wrote. He makes a logical strategy, which when the viewers sees these status, they will believe and become interested to visit Samosir. The user makes statements based on the conditions of the photos that the user adds that purpose to attract the attention of the viewers. Secondly, the user uses logos strategies by adding the facts such as the activities or events to be held in Samosir. For example the user specifies the date, month or year of the implementation of the event. The user promote the Samosir tourism with various activities or events such as entertainment events, competitions, that it is in order to gain the belief of the viewers.

Beside from the adding of event's time that will be held in Samosir, showing the locations of tourist attractions is also one of the logical statements that can attract viewerss' confidence. The user describes the condition of one of the samosir attractions, then he gives the location where the tourist can be found. As the example of the visit samosir status "Sidabutar Tomb located in Tomok".

\section{CONCLUSION AND SUGGESTION}

\section{Conclusion}

This study deals with persuasive strategies of samosir promotion in visit samosir facebook page. There are 60 status from visit samosir as the data had analized. The analysis of the study shows that from the 7 types of persuasive technique by Keraf, 
there were only six types of persuasive technique in this study. And the most usual types of persuasive technique that the user use is suggestion. It is due to invite or persuade people to accept the certain conviction without giving a principle or logical belief. It is involved getting the viewers to accept the promoting without thinking an idea, belief, and action. The second, while there were six types of persuasive technique that found in this research, the three strategies of persuasive by Aristotle used in this study. They were Ethos, Phatos and Logos. Logos strategy become one of the most commonly strategy used in visit samosir facebook page. When the user use Logos strategy in promoting of Samosir tourism, it shows the user give evidences and logical information about the tourism. The user persuade the viewers by giving them the fact information or reason. Such as, the user input the date of the events that will be held in Samosir, the user inform about the location of tourist attraction in Samosir, and the user make a statement of features based on the photos that he share in the wall of visit samosir.

\section{Suggestion}

Having seen the result of this study, the writer would like to offer some suggestion to be considered by those who are interested in studying about persuasion and in making futher reserach about it. The first, It is suggested that the student of English literature should learn more about the use of language especially in Social Networking such as Facebook as the one easier way to connect with the other people. The second, It is suggested to the other researcher should make futher researcher about persuasion in the other tourism promotion, so it can help them to make a good strategy to persuade people. The third, It is suggested that the user of visit samosir must care for the strategy and the technique that they use to persuade people. So it can get their belief and their interesting to Samosir island. 


\section{REFERENCES}

Boyland, Emma J. (2010). Persuasive techniques used in television advertisements to market foods to UK children. UK.Department of Experimental Psychology, University of Liverpool.

Budiani, Yunita Sari. (2014). Sebuah Analisa persuasive tekhnik yang digunakan dalam iklan kosmetik..Surabaya. Fakultas Sastra dan Budaya. UIN Sunan Ampel.

Carlton, William. 1970. Aristotle Physics Book I \& II. Oxford: Oxford University Press.

Ferreira, Silvia Nerea Sastre. (2014). Persuasive Language in Tourism Webpages: Official Webpages of Los Angeles, Seattle and Washington. Universidad de Valladolid.

http://whatis.techtarget.com/definition/Facebook (Accessed On Feb 3th, 2017 11:20 p.m)

http://www.facebook.com/pg/VisitSamosirIsland/posts/?ref=page_internal (Accessed On April 13, 201701.15 a.m)

Keraf, Gorys. (2000). Argumentasi dan Narasi. Jakarta: Gramedia.

Mulholland, J. (1994). Handbook of persuasive tactics: A practical language guide. London: Routledge.

Pradopo, Joko. (2000). Metodologi Penelelitian Sastra. Yogyakarta: PT. Handika Graha Widia Yogyakarta.

Rezaei, Sohrab. (2016). Language and Power: "The Use of Persuasive Techniques in Iran and U.S. President Speeches".

Rizka, Evin Maya Aulia. (2016). Persuasive Technique in Nike Advertisement.

Universitas Islam Negeri Islam Malang. 
S.A Kenechukwu. (2013). Behind Advertising: The Language of Persuasion. Nigeria: Department of Mass Communication, Madonna University Okija.

Safitri, I. (2013). Persuasive Strategies of Commercial and non commercial Advertisement on Time Magazine.

Sagala, Renni dkk. (2016). Mini Research: Foreign Tourists Perception for The Developtment of Samosir Tourism. Medan: State University of Medan.

Saragih, Amrin. (2014). Discourse Analysis: A study on discourse based on systemic function linguistic theory. Medan: State University of Medan.

Sitorus, Widy dkk. (2016). Mini Research: The Persuasive Technique in Samosir Tourism Promotion. Medan: State University of Medan.

Situmorang, Maria Klara Timorina. 2016. Rhetorical Style in the headline news of the daily kompas. State University of Medan.

Strauss, Anselm. (2003). Basic of Qualitative Research. Yogyakarta: Pustaka Pelajar.

Tim Perfect Com. (2011).Tutorial Praktis Menggunakan Facebook. Surabaya: Indah.

Thompson, Peter. (1998). Persuading Aristotle. Australia: The Electric Book Company. 